\title{
Kiskunsági alluviális síkság talajtani-domborzati sajátságainak térinformatikai alapú vizsgálata, különös tekintettel a feltételezett talajvízszint-változásokra
}

\author{
BAKACSI ZSÓFIA
}

MTA Talajtani és Agrokémiai Kutatóintézet, Budapest

\section{Bevezetés}

A korszerü térinformatikai módszerek jó és új lehetőséget nyújtanak a természeti viszonyok és a talajviszonyok közötti összefüggések részletes és okokozat feltáró elemzésére. A Kiskunság alluviális síkságán végzett kutatásaink során ezen összefüggések pontosabb feltárására törekedtünk, különös tekintettel a térség egyik fontos környezeti problémájára, a feltételezett talajvízszint-változások talajtani következményeinek megállapítására.

A Magyar Állami Földtani Intézet (MÁFI) apajpusztai mintaterületének térinformatikai alapokon nyugvó vizsgálatának célja egyrészt a területen a századfordulón végzett lecsapolási-árvízmentesítési munkálatok után érvényesülő felszínalakító folyamatok jellemzése volt, másrészt pedig annak vizsgálata, hogy a mintaterület környezetének tartós változását előidéző regionális folyamatok (pl. a talajvízszint megváltozása) milyen hatással lehetnek a felszínalakulásra, elsősorban a talajképződésre. A munka egyik állomása a mintaterület talajtani-domborzati sajátságainak és a rendelkezésre álló talajvízszint-adatoknak térinformatikai alapú vizsgálata. A mintaterület elhelyezkedését mutatja az 1. ábra.

A Duna-völgy talajtakarójának felépítésében jelentős területi részarányúak a sós és szikes talajok (SCHERF, 1935; SZABOLCS \& JASSÓ, 1961; VÁRALLYAY et al., 1984). A duna-völgyi szikesek kialakulásában elsődleges szerepet játszanak a nagy sótartalmú felszín alatti vizek áramlásai (TÓTH J., 1984, 1995), és a pangó sós talajvíz (ERDÉLYI, 1967a,b, 1979; VÁRALLYAY, 1967), ezért a Dunavölgyben érvényesülő áramlási rendszerek hosszú távú megváltozása (MAJOR \& NEPPEL, 1988; BERÉNYI \& ERDÉLYI, 1990; ROTÁRNÉ, 1994), illetve a talajvízszint jelentős mértékủ süllyedése-emelkedése (SZALAY \& LÓCZY, 1992) hatással lehet a talajtulajdonságok térbeli elterjedésére, a szikes talajképződési folyamatokra. HARMATI (2000) a szikesekben beindult sókilúgozódási folyamatokról számol be több évtizedes megfigyelési adatokra támaszkodva. A mintaterület

* A Magyar Talajtani Társaság és a Magyarhoni Földtani Társulat Mérnökgeológiai Szakosztálya 2000. február 9-én, a szikesedés témakörében rendezett előadóülésén elhangzott előadás anyaga 


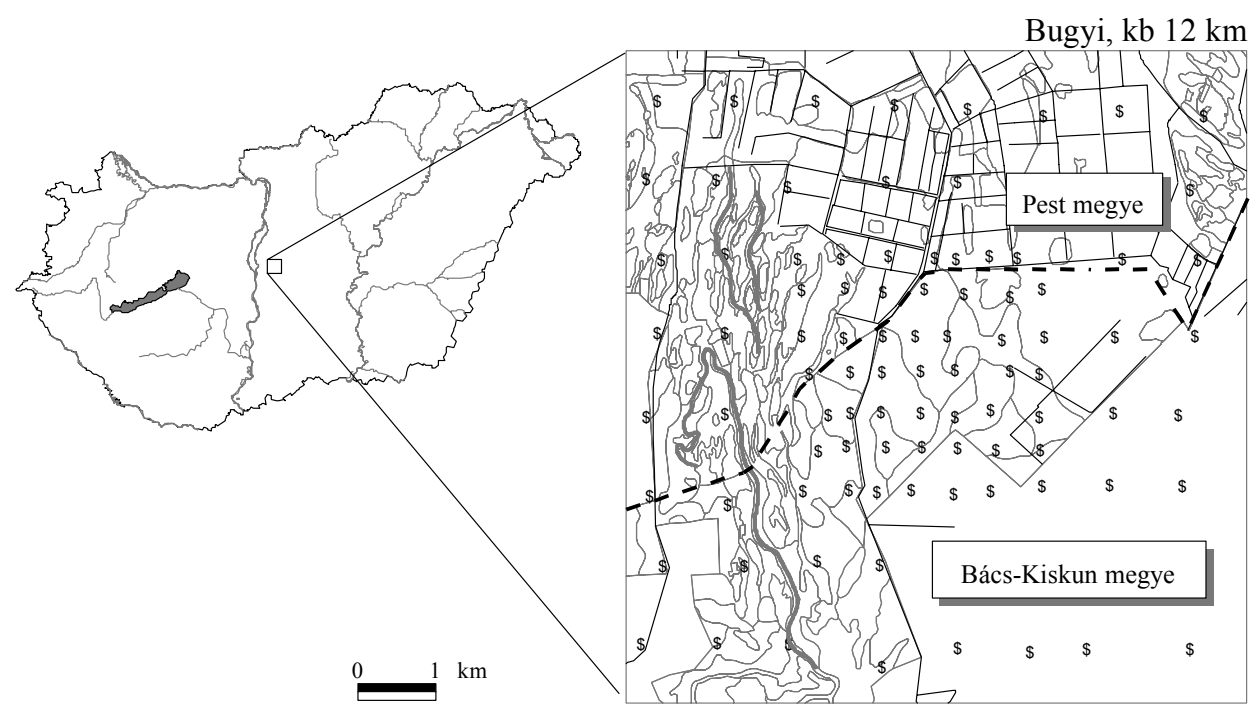

Kunszentmiklós, kb 500 m

\section{1. ábra}

A mintaterület elhelyezkedése. A térképvázlat feltünteti az agrogeológiai fúráspontokat (fekete háromszögek), az üzemi genetikus talajtérképen elkülönített talajfoltok kontúrját (vékony szürke vonal), a csatornahálózatot (vékony fekete vonal) a természetes vízfolyásokat (vastag szürke vonal) és a megyehatárt (szaggatott vonal)

egy része a Kiskunsági Nemzeti Parkhoz tartozik, melyre 1974-1975-ben genetikus üzemi talajtérkép (1:10 000) készült, 1979-1980-ban pedig 1:25000 méretarányú termőhely-térképezés folyt, amelyhez a kapcsolódó részletes talajvizsgálatok is elkészültek az MTA Talajtani és Agrokémiai Kutatóintézetben (KNP jelentés, 1980).

A vizsgálathoz szükséges a jelenlegi állapot (domborzat, talajtakaró, talajvíz mélysége és minősége stb.) olyan formában történő feldolgozása, amely a későbbiek során alkalmas a bővítésre, kiegészítésre. A térbeli adatok kezeléséhez, tárolásához, elemzéséhez és megjelenítéséhez ESRI (Environment Systems Research Institute) GIS szoftvereket: PC ARC/INFO-t és az ArcView moduljait (Spatial Analyst) használtunk.

\section{Adatbázis, módszerek}

\section{Agrogeológiai adatok}

A mintaterületen az agrogeológiai felvételezés része volt egy átfogó, Alföldtérképezési programnak (RÓNAI, 1985). A mintaterületen a MÁFI Agrogeológiai Osztálya 1987-ben 97 db sekélyfúrást telepített négyzethálósan, 1000, ill. 
500 m-es hálóban, majd 1997-ben megismételték a mintavételt. A fúrások általában a felszínhez legközelebb lévő első homokos kavics, kavicsos homok szintig mélyültek, mélységük $3,5-5 \mathrm{~m}$ között változik. A fúrási szelvények anyagából a felső $2 \mathrm{~m}$-ben $0,5 \mathrm{~m}$-enként, ezalatt legalább m-enként vettek átlagmintát; ha a szelvényben réteghatár-változást észleltek a mintavételezés értelemszerủen rétegenként történt. A mintákból szedimentológiai és kémiai elemzés készült (szemcseméret-eloszlás, $\mathrm{pH}, \mathrm{CaCO}_{3}$, mikroelemek). A fúrások mindegyike elérte a talajvizet, melynek nyugalmi szintje 0,4-2 m között volt; a vett vízmintákból kémiai elemzést végeztek.

A mintaterület közettani felépitése - A fúrások alapján szerkesztett kőzettani szelvények tanúsága szerint a mintaterületre az üledékek hármas tagozódása jellemző. A fúrások által megütött legalsó szintben, a rétegsor alján kavicsos homok található, jelentkezési mélysége általában 3,5-5 m közötti, kavicstartalma erősen változó (a fúrásokkal feltárt üledékben 10 és $30 \%$ között ingadozott az $5 \mathrm{~mm}$-nél nagyobb átmérőjü szemcsék aránya). Feltárt legnagyobb vastagsága $1,5 \mathrm{~m}$.

Közvetlenül a kavicsos homokra különböző szemcseméretü (közep,- apró,vagy finomszemü) homok települ, feltárt legnagyobb vastagsága 5,0 m, gyakran tartalmaz agyagos-kőzetlisztes lencséket, közberétegzéseket. A finomhomokos kifejlődés a felszín közelben általában lencseként települ apróhomokba vagy középhomokos apróhomokba, fedője mindig finomszemcsés ártéri üledék.

A finomszemcsés agyagos homok, aleurit, homokos agyag, agyag képződmények egyrészt kisebb lencsékben találhatók az üledék fö tömegét adó homoktestben, másrészt egymást váltva, illetve összefogazódva alkotják a felszínt legfeljebb $1,5 \mathrm{~m}$ vastagságban, lepelként borító finomszemcsés ártéri üledékanyagot.

$\mathrm{Az}$ agrogeológiai felvételezésből származó adatok a fúrási pontokhoz rendelve, pontadatok formájában állnak rendelkezésre.

\section{Talajtani adatok}

Az agrogeológiai mintaterület északi része közigazgatásilag Pest megyéhez, déli része pedig Bács-Kiskun megyéhez tartozik. A Kiskunsági Nemzeti Park területét is érintő részén az MTA TAKI vezetésével folyt 1:25000 méretarányú termőhely-térképezés, $\mathrm{s}$ ehhez kapcsolódóan részletes talajvizsgálatok is készültek (KNP jelentés 1980, VÁRALLYAY et al., 1984). Az ismertetendő talajtanitérszíni összefüggések vizsgálatához a Pest megyéhez tartozó terület genetikus üzemi talajfelvételezési adatait használtuk fel. A rendelkezésre álló talajtani adatok részletesebb információkkal szolgálnak a területről, mint az agrogeológiai felvételezés, méretaránya 1:10 000-es. A területen az 1975-ben végzett 1:10 000 méretarányú genetikus üzemi talajtérképezés csak az egykori mezögazdasági területeket érintette, $\mathrm{s}$ mivel a mintaterület egy része a Kiskunsági 
Nemzeti Parkhoz tartozó védett terület, az egészre nem állt rendelkezésre a genetikus üzemi talajtérkép. Az 1975. évi térképezés 3096 hektárt érintett, a területen 22 talajtípust-altípust különböztettek meg a több mint 200 talajszelvény adatai alapján. A leírt talajtípusok az öntés és réti talajoktól indulva a szikeseken át a csernozjomokig foglalják magukba az alluviális síkság talajképződményeit.

Talajvizre vonatkozó adatok - A területen három alkalommal került sor kiterjedt, a talajvizet érintő mintavételezésre. Mind a talajtani, mind az agrogeológiai felvételezés során születtek a talajvíz mélységére, megütött, ill. nyugalmi szintjére, vízkémiai összetételére vonatkozó pontadatok. Az agrogeológiai mintavételi hálózatra nincs monitoring-szerü rendszeresen mért talajvíz adat, 1987-ből 38, 1997-ből pedig 30 fúrási adattal rendelkezünk a talajvíz megütött szintjére vonatkozóan. Néhány konkrét adat alapján feltételezhetjük, hogy az 1975. évi talajfelvételezés során feltárt 241 szelvény mélysége a talajvíz aktuális mélységével volt azonos, ami az agrogeológiai felvételezések során feltárt talajvíz megütött szintjével azonosítható. A talajvízszint szezonális ingadozása jelentős lehet a területen, de a hosszú távú talajvízszint-változás becslésében mégis kezelhetjük egységesen a rendelkezésre álló adatokat, ha figyelembe vesszük egyrészt a felszín alatti, összefüggő homoküledék kiegyenlítő, az ingadozást mérséklő hatását, illetve azt, hogy valamennyi mintavételezés nyáron történt, feltételezhetően egy hosszabb, száraz periódus után, mivel nedves idöszakban a szikes terület szinte járhatatlan.

\section{Domborzati adatok}

A domborzati adatok részletessége az EOTR 1:10 000-es szelvények felbontásának felel meg. A terület szinte teljesen sík, nagyrészt 95,5 m-en fekvő, agyagos homokkal és iszappal borított felszínéböl csak a mintaterület keleti részén lévő, a Hátság felé átmenetet mutató homokdombok, illetve a Baki ér vízfolyását szegélyező dűnék emelkednek ki, de a dombtetők magassága alig haladja meg a $100 \mathrm{~m}$-t.

A domborzati sajátosságokból eredően az 1:10 000-es EOTR topográfiai térképeken ábrázolt és egyben a digitális domborzatmodell alapjául szolgáló szintvonalak csak 0,5 m-enként követik egymást, a kiindulási szelvények nem teszik lehetővé a terep felszínének pontosabb nyomon követését, ezért a belőle származó terepmodell magassági felbontása is csak félméteres.

\section{A vizsgálat módszerei}

A térinformatikai vizsgálati módszerek jól ismertek a talajtani kutatásban, a szikesek vizsgálatában már korábban is eredményesen alkalmazásra kerültek (KUTI et al., 1999a,b; TÓTH et al., 1998; TÓтH \& KUTI, 1998, 1999a,b). A min- 
taterületen megvizsgáltam az 1:10 000 méretarányú genetikus üzemi talajtérképezés során feltárt talajtípusok és azok térszíni helyzete közötti összefüggést az adott területen, majd az eredményt összehasonlítottam a talajvíz szintjére vonatkozó adatokkal. Az adatfeldolgozás vázlatát mutatja a 2. ábra.

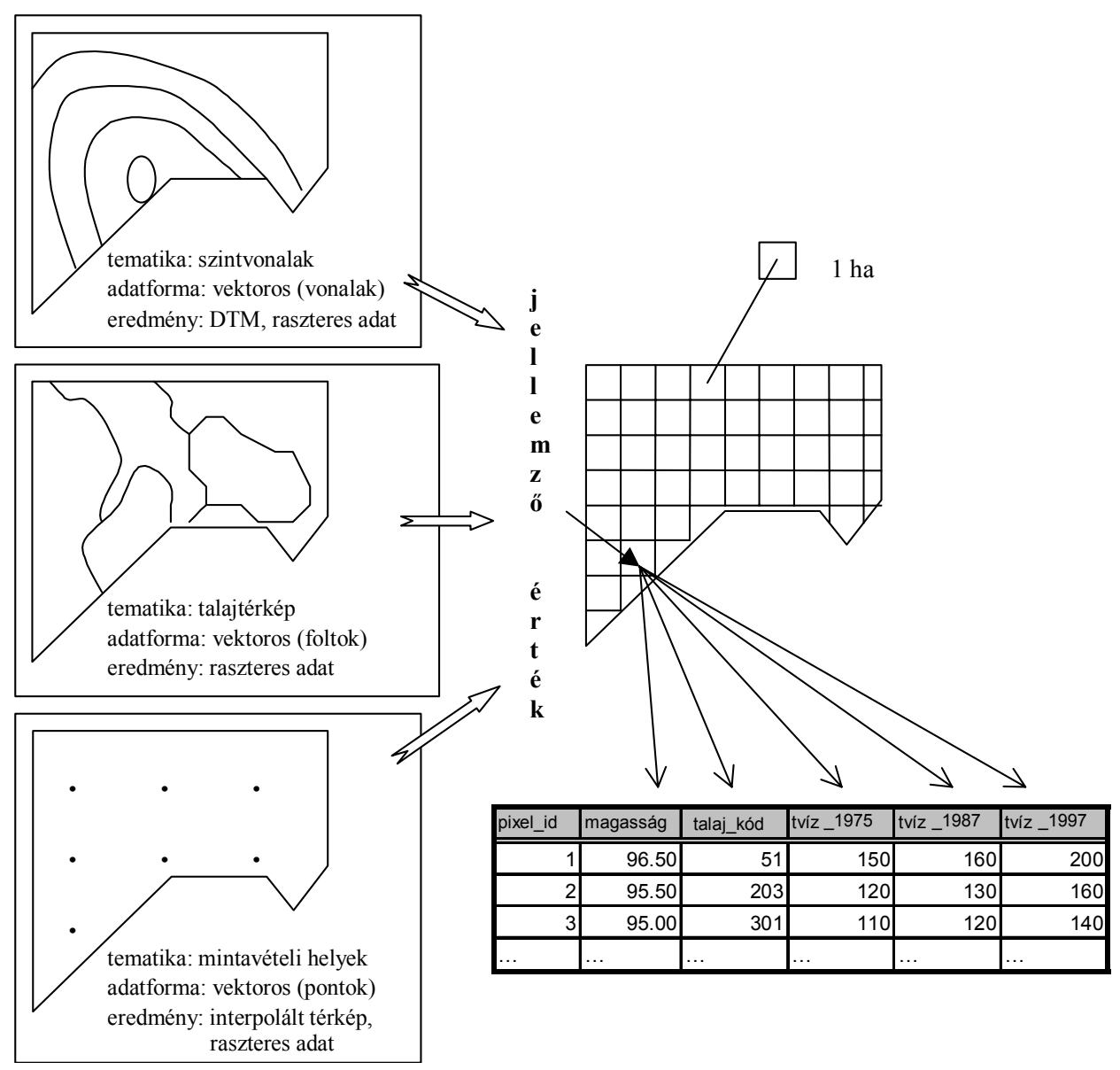

\section{2. ábra}

Az adatfeldolgozás főbb lépései. A vázlat feltünteti a kiindulási adatok tematikáját, adatformátumát és azt, hogy a kiindulási adatokat az átalakítások eredményeként milyen formában használtuk fel az elemzésekben

Az elemzések előkészítésére egy 100 x 100 m-es (1 ha-os), szabályos rácshálót kellett létrehozni. A rácshálón belül 3096 hektárra van értékelhető talajtani információ. A talajtérkép elöször vektoros formában került ábrázolásra, majd azt az elemzések elvégzéséhez egy 10 x 10 m felbontású raszteres állománnyá 
alakítottuk. A pontadatok interpolációjával a talajvíz adatokat kiterjesztettem a mintaterületre.

A rácshálót ráhelyezve a raszteres formátumú tematikus térképekre (a lépcsős terepmodellre, a talajtérképre és az interpolált talajvíz térképre), lehetővé vált együttes kezelésük. Az egyes rácselemekhez mindig azt az értéket rendel-

\section{1. táblázat}

A magassági értékek talajtípusonkénti összegzése a mintaterület Pest megyéhez tartozó területére

\begin{tabular}{|c|c|c|c|c|c|}
\hline Talajtípus & $\begin{array}{l}\text { Terü- } \\
\text { let (ha) }\end{array}$ & $\begin{array}{c}\text { Átlag } \\
\text { (m) }\end{array}$ & $\begin{array}{l}\text { Min. } \\
\text { (m) }\end{array}$ & $\begin{array}{c}\text { Max. } \\
\text { (m) }\end{array}$ & Szórás \\
\hline 3. $\operatorname{csoport}(96,0 \mathrm{~m}<)$ : & 81 & 97,37 & 95,5 & 100,00 & 0,98 \\
\hline terasz csernozjom talajok & 2 & 98,50 & 97,00 & 100,00 & 21,21 \\
\hline karbonátos humuszos homoktalajok & 51 & 96,92 & 95,00 & 100,00 & 12,80 \\
\hline többrétegü humuszos homoktalajok & 28 & 96,70 & 95,50 & 98,00 & 9,75 \\
\hline 2. $\operatorname{csoport}(95,5-96,0 \mathrm{~m})$ : & 185 & 95,61 & 95,00 & 98,00 & 0,23 \\
\hline réti csernozjom talajok & 81 & 95,78 & 95,00 & 98,00 & 6,71 \\
\hline mélyben sós réti csernozjom & 38 & 95,66 & 95,00 & 96,00 & 3,87 \\
\hline csernozjom réti talajok & 37 & 95,57 & 95,00 & 96,00 & 3,99 \\
\hline mélyben sós réti talajok & 20 & 95,55 & 95,00 & 96,00 & 2,24 \\
\hline mélyben szolonyeces réti csernozjom & 9 & 95,50 & 95,50 & 95,50 & 0,00 \\
\hline 1. csoport $(<95,5 \mathrm{~m})$ : & 2706 & 95,10 & 95,00 & 96,00 & 0,12 \\
\hline réti öntéstalajok & 15 & 95,47 & 95,00 & 96,00 & 2,97 \\
\hline mélyben szolonyeces réti talajok & 145 & 95,18 & 95,00 & 95,50 & 2,41 \\
\hline kérges réti szolonyec talajok & 732 & 95,12 & 94,50 & 96,00 & 2,21 \\
\hline öntés réti talajok & 81 & 95,10 & 94,50 & 96,00 & 2,47 \\
\hline szolonyeces réti talajok & 99 & 95,10 & 95,00 & 96,00 & 2,70 \\
\hline karbonátos szoloncsák talajok & 50 & 95,09 & 94,50 & 96,00 & 2,83 \\
\hline szulfátos szoloncsákos réti talajok & 125 & 95,08 & 95,00 & 95,50 & 1,84 \\
\hline karbonátos szoloncsák-szolonyec t. & 374 & 95,07 & 95,00 & 96,00 & 1,82 \\
\hline réti talajok & 869 & 95,07 & 94,50 & 96,00 & 2,48 \\
\hline közepes réti szolonyec talajok & 51 & 95,06 & 94,50 & 95,50 & 1,92 \\
\hline karbonátos szoloncsákos réti talajok & 3 & 95,04 & 95,00 & 95,50 & 1,29 \\
\hline humuszos öntéstalajok & 54 & 95,01 & 94,50 & 95,50 & 1,81 \\
\hline lápos réti talajok & 93 & 95,00 & 94,50 & 95,50 & 1,65 \\
\hline szolonyeces lápos réti talajok & 15 & 95,00 & 95,00 & 95,00 & 0,00 \\
\hline térképezett terület Pest megyében, ha & 2972 & & & & \\
\hline egyéb terület (erdő, település) & 124 & & & & \\
\hline összes terület (ha) & 3096 & & & & \\
\hline
\end{tabular}

Megjegyzés: A táblázatban a talajtípusok elnevezésére a kiindulási genetikus üzemi talajtérkép nevezéktanát vettem alapul, az egyes csoportokon belüli sorba rendezés az átlagos magassági értékek alapján történt 
tem hozzá, amely az alatta lévő tematikus térképen a leggyakrabban fordult elö. A hozzárendelés eredményeként az 1 ha-os felbontású rácsháló minden elemére rendelkezésre állt egy jellemző magassági érték és egy talajtípus kód. A magassági értékeket a talajtípusok szerint összegeztem, majd sorba rendeztem. (1. táblázat). Az egyes csoportokra jellemző magassági értékek - egytényezős egyszerü varianciaanalízis alapján (F-statisztikával, 95 \%-os valószínüségi szint mellett) - egymástól szignifikánsan eltérőnek bizonyultak.

\section{Vizsgálati eredmények}

A mintaterület tengerszint feletti magassági értékeit a talajtípusokkal, illetve a talajvízszint adatokkal vetettem össze. A kiindulási szintvonalak viszonylag nagy magassági ugrásai ellenére az egyes talajtípusok térbeli pozíciója összefüggést mutat a talajtípusok hidromorf sorával, a legalacsonyabb térszíni helyzetben a lápos réti és szikes talajokat találjuk, köztes helyzetben a mélyben sós változatokat és a csernozjom felé átmenetet mutató talajokat, míg a legmagasabb térszíneken csernozjom talaj fordul elő. A domborzat és az észlelt talajvízszint értékek összevetése a területen a talajvíz szintjének folyamatos süllyedését mutatja.

\section{A Digitális Terepmodell és a talajtérkép összevetése}

A talajtípusokat a tengerszint feletti magasságuk átlaga alapján sorba rendezve, az egyes talajtípusokra kapott átlagérték önmagában kicsit megtévesztő, pl. az öntés réti talajnál az átlag 95,1 m, a szélsőértékek: 95,0 ill. 96,0 m; ez esetben a 95,1 m-es átlag csak azt tükrözi, hogy a talajtérképre helyezett 1 ha-os felbontású grid e talajtípust képviselő rácselemeiben a 95,0 m értékü magassági elemek vannak túlsúlyban (3. ábra).

A mintaterület legnagyobb része 95,5 m tengerszint feletti magasságon fekszik, ez a magasság és a hozzá közel álló értékek tehát a legjellemzőbbek. Aszerint, hogy az adott talajtípusra jellemző átlagmagasság milyen tartományba esik, három csoportot különböztethetünk meg:

1. csoport: az átlag kisebb, mint $95,5 \mathrm{~m}$,

2. csoport: az átlag 95,5 -96,0 m közé esik,

3. csoport: az átlag nagyobb, mint $96,0 \mathrm{~m}$.

A magassági tartományok szerint elkülönitett csoportok jellemzöi:

1. csoport $(<95,5 \mathrm{~m})$. - Elsősorban vízhatás alatt álló és szikes talajok tartoznak ebbe a csoportba. A legmélyebb térszíni fekvésben a lápos réti talajok és a szolonyeces lápos réti talajok találhatók. Ezeken kívül humuszos öntéstalajok, réti talajok és azok sófelhalmozódással különböző formában érintett altípusai 


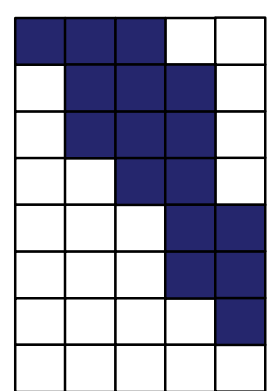

adott talajtípus

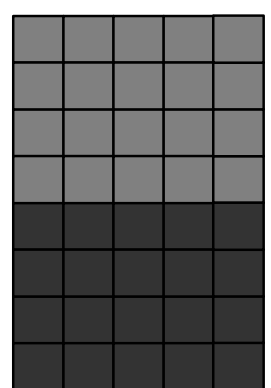

magassági értékek

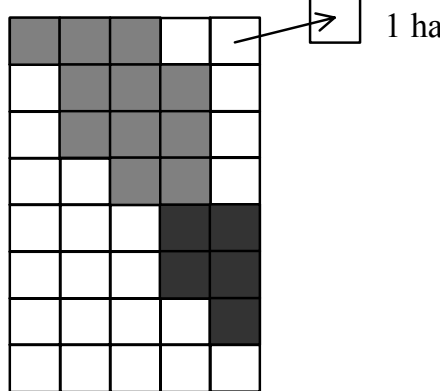

átlag képzése az adott típusra

\section{3. ábra}

Egy adott talajtípusra jellemző átlagos magassági érték származtatása az egy hektáros grid alapján. A magassági értékek átlaga azt tükrözi, hogy mely magassági elemek dominálnak az adott talajtípus előfordulási területén belül

(karbonátos, szoloncsákos, szulfátos-szoloncsákos) és különböző típusú szikes (szoloncsák, szoloncsák-szolonyec, réti szolonyec) talajok fordulnak elő. A genetikus üzemi talajtérképezés során megkülönböztetett 22 talajtípus (altípus) több, mint fele ebbe a csoportba tartozik. A csoportban legnagyobb területi részaránnyal a réti talajok szerepelnek, ezt követik a kérges réti szolonyecek és a karbonátos szoloncsák-szolonyec talajok. E csoporton belül a különböző szikes és réti talajképződmények egymáshoz viszonyított helyzete a magasság átlagok alapján nem állapítható meg pontosan, de tulajdonságai alapján (erőteljes vízhatás, felszín közeli nagy sótartalom, a csernozjom jelleg hiánya) jól elkülönül a többitől.

2. csoport $(95,5-96,0 \mathrm{~m})$. - A vízhatás továbbra is jelentős, de e mellett a csernozjom-jelleg megjelenése is megfigyelhető. Elsősorban csernozjom réti és réti csernozjom talajok, illetve ezek mélyben sós altípusai jellemzőek erre a csoportra. A sós talajvíz már nem emelkedik a felszín közelébe, a szelvényben megnövekedett sótartalom csak a mélyebb szintekben jelentkezik. Ebbe a csoportba sorolható a térképezett talajtípusok-altípusok egyharmada.

3. csoport $(96,0 \mathrm{~m}<)$. - 96,0 m magasság felett már nem kell vízhatással számolni, a réti jelleg háttérbe szorul, a víz hatásától mentesen képződött talajok tartoznak ide. A mintaterület kiemelkedő térszíneit leginkább a Baki ér vízfolyása mentén húzódó homokdűnék, illetve a Duna-völgytöl keletre húzódó hátsági területek felé átmenetet mutató homokdombok képviselik. A talajképző laza üledéknek köszönhetően itt föleg homoktalajokat (karbonátos, ill. többrétegü homoktalajok), a legmagasabb térszíneken pedig, mindössze 2 ha-on, terasz csernozjomokat találunk. 
A Digitális Terepmodell és a talajvízszint összevetése

A talajvízre vonatkozó adatokat a korábban elkülönített magassági tartományokra vonatkoztatva elemeztük (2. táblázat). A kiindulási adatcsoportok elemszáma eltérő, ami a talajtani és agrogeológiai térképezés eltérő méretarányából fakad.

\section{2. táblázat}

A megütött talajvíz átlagos mélysége a felszín alatt az elkülönített magassági tartományokban

\begin{tabular}{|c|c|c|c|c|c|c|}
\hline \multirow{2}{*}{$\begin{array}{c}\text { Magassági } \\
\text { tartomány, } \\
\mathbf{m}\end{array}$} & \multicolumn{2}{|c|}{ Átlagos talajvízmélység, cm } & \multicolumn{3}{c|}{ A változások összegzése, cm } \\
\cline { 2 - 7 } & $\begin{array}{c}\mathbf{1 9 7 5} \\
\mathbf{n = 2 4 1}\end{array}$ & $\begin{array}{c}\mathbf{1 9 8 7} \\
\mathbf{n = 3 8}\end{array}$ & $\begin{array}{c}\mathbf{1 9 9 7} \\
\mathbf{n = 3 0}\end{array}$ & $\begin{array}{c}\mathbf{1 9 7 5}- \\
\mathbf{1 9 8 7}\end{array}$ & $\begin{array}{c}\mathbf{1 9 8 7}- \\
\mathbf{1 9 9 7}\end{array}$ & $\begin{array}{c}\mathbf{1 9 7 5}- \\
\mathbf{1 9 9 7}\end{array}$ \\
\hline $96,0<$ & 143 & 170 & 198 & -27 & -28 & -55 \\
$95,5-96,0$ & 133 & 138 & 157 & -5 & -19 & -24 \\
$<95,5$ & 112 & 121 & 142 & -9 & -21 & -30 \\
\hline
\end{tabular}

Az 1975-1987 közötti időszakban a legmélyebb talajvízállású, térszínileg kiemelt (96,0 m feletti) területeken a talajvízszint csökkenésének üteme mintegy 2 cm/év, az 1987-1997 közötti időszakban az intenzitása hasonló volt. 19751987 között a süllyedés mértéke csekély a térszínileg mélyebben elhelyezkedő területeken, de felgyorsult az 1987-1997 közötti időszakban, amikorra mintegy $20 \mathrm{~cm}$-nyi talajvízszint-süllyedést regisztrálhatunk. A mélyebb fekvésủ területeken a süllyedés intenzitása nőtt, az 1987-1997 közötti érték legalább kétszeres, mint a megelőző időszakban.

TÓTH és VÁRALLYAY (2001) és VÁRALLYAY (1966a,b) szikes talajszelvényekben mért részletes sómérleg adataiból, illetve a HARMATI (2000) által közölt megfigyelési adatokból nyilvánvaló, hogy a 70-es éveket megelőzően a Duna-Tisza köze déli részén tapasztalt nagyarányú talajvízszint-csökkenésnek mérhető hatása nem volt a területre, s ezért a területet jellemző 1975. évi talaj-, vegetáció-, és talajvíz adatokat referenciaként tekintettem a terület környezeti állapotváltozásának regisztrálásában.

A talajvíz megütött szintjének átlagos terep alatti mélységének összevetése 1975-ben és 1997-ben azt mutatja, hogy a legmélyebb térszíni fekvésben lévő talajok (pl. a réti talajok) alatt a talajvíz szintje mélyebben helyezkedett el 1997ben, mint a köztes térszíni pozícióban lévő talajok (pl. réti csernozjomok) alatt 1975-ben. Az átlagos talajvízszint 1997-ben a réti csernozjom „övezetben” mélyebben húzódott, mint 1997-ben a kiemelt térszíni helyzetü homoktalajok alatt (1. 4. ábra).

A talajvízszint süllyedése azt eredményezi, hogy a területre jellemző talajszelvények kialakításában eddig döntő jelentőségủ hidromorf hatás kisebb mértékben érvényesülhet, a szikes szelvényekben a sófelhalmozódási szintek 
mélyebbre húzódnak, egy lassú átalakulási folyamat során a növényzet számára döntő felszíni-felszín közeli talajtulajdonságok megváltoznak, s ez maga után vonja a védett élőhelyek vegetáció-összetételének megváltozását is.

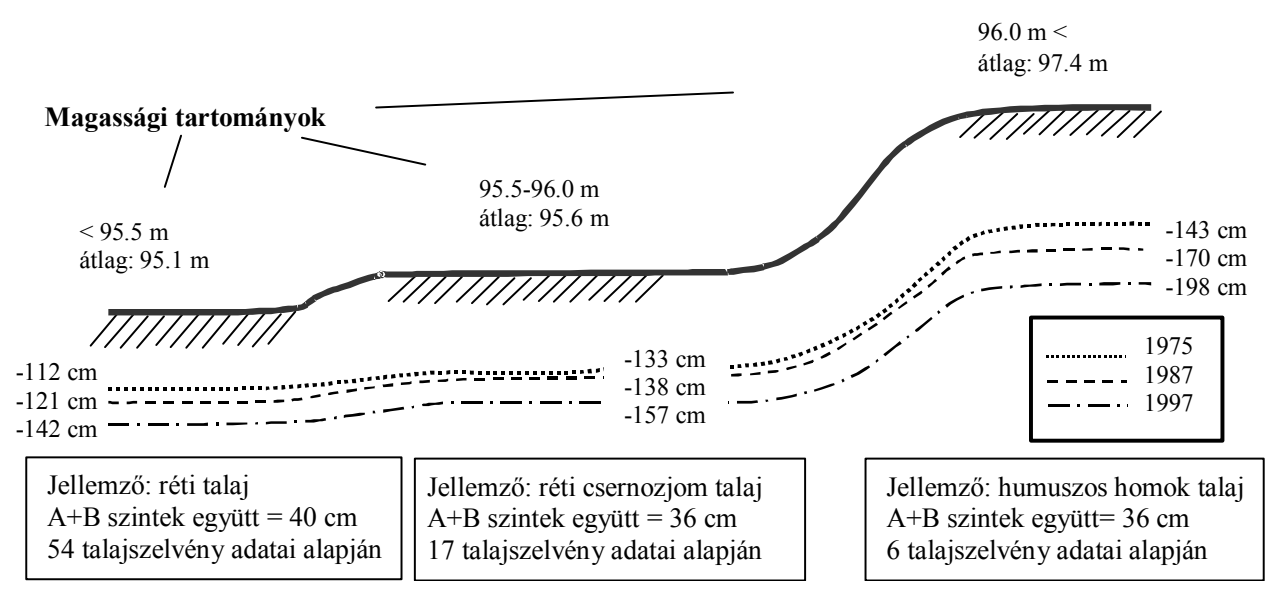

\section{4. ábra}

A megütött talajvízszint átlagos mélysége a felszín alatt 1975-ben, 1987-ben és 1997 ben. A magassági tartományokat a magassági értékük átlaga jelöli. Az ábra feltünteti az egyes magassági tartományokra jellemző, legnagyobb területi kiterjedésű talajokat és azok A+B szintjeinek együttes vastagságát

\section{Összefoglalás}

Az olyan regionális környezeti hatások, mint pl. a felszín alatti vízáramlás tartós megváltozása elöször csak egyes talajképződési folyamatok intenzitásának változásában jelentkeznek. Hatásuk nem mérhető azonnal a különböző talajtípusok térszíni helyzetének megváltozásában, mert a talajoknak a megváltozott környezeti feltételekhez való igazodása több évtizedet is igénybe vehet. A talajok térbeli elhelyezkedése összefüggést mutat a talajtípusok hidromorf sorával (catena). A vizsgált területen az 1980-as évek vége óta felgyorsult talajvízszint-csökkenési és ebből eredő szárazodási folyamat észlelhető. A Kiskunsági Nemzeti Park vizsgált területén a talajvízszint további süllyedése a védett szikes élőhelyek degradációjához vezethet, mert erősödik a szikes talajok sztyeppesedési folyamata, és a korábban az extrém körülményekhez adaptálódott sótürő növényzet a mélyebb területek felé húzódik. 


\section{Irodalom}

BERÉNYI P. \& ERDÉLYI M., 1990. A rétegvíz szintjének süllyedése a Duna-Tisza közén. Vízügyi Közlemények. 72. (4) 377-396.

ERDÉLYI M., 1967a. A Duna-Tisza közének vízföldtana I.. Hidrológiai Közlöny. 1967/6 331-340.

ERDÉLYI M., 1967b. A Duna-Tisza közének vízföldtana II.. Hidrológiai Közlöny. 1967/8 353-365.

ERDÉLYI M., 1979. A magyar medence hidrodinamikája. VITUKI kiadvány. Budapest.

HARMATI I., 2000. A Duna-völgy talajvíz-viszonyainak változása a vízrendezés hatására. Agrokémia és Talajtan. 49. 400-416.

Jelentés a Kiskunsági Nemzeti Park részére 1979-80-ban végzett munkálatokról, 1980. MTA Talajtani és Agrokémiai Kutató Intézete. Budapest.

KUTI, L. et al., 1999a. Relationship between the data of agrogeological maps and the extent of salt-affected soils on the Great Hungarian Plain. Agrokémia és Talajtan. 48. $501-516$.

KUTI, L. et al., 1999b. Analysis of regional soil salinization by GIS. In: Proc. Int. Symp. on Sustainable Management of Salt-affected Soils in the Arid Ecosystem. 21-26 Sept, 1997. (Ed.: Elgala, A.) 106-122. Ain Shams University. Cairo.

Major P. \& NePPel F., 1988. A Duna-Tisza közi talajvízszint-süllyedések. Vízügyi Közlemények. 70. (4) 605-620.

RóNAI A., 1985. Az Alföld negyedidőszaki földtana. Geologica Hungarica ser. Geol. 21. Müszaki Könyvkiadó. Budapest.

ROTÁRNÉ SZALKAI Á., 1994. Rétegvizek piezometrikusszint-csökkenése a Duna-Tisza közén. In: II. Nemzetközi Környezetvédelmi Konferencia, Kecskemét, 1994. május 4-6. 28-33.

SCHERF E., 1935. Alföldünk pleisztocén és holocén rétegeinek geológiai és morfológiai viszonyai és ezeknek összefüggése a talajalakulással, különösen a szikképződéssel. Magyar Kir. Földt. Int. Évi Jelentés 1925-1928. 265-301.

SZALAY, J.\& LócZY, D., 1992. Some trends in groundwater level changes on the Danube-Tisza interfluvial region, Hungary. VITUKI kiadvány. Budapest.

SZABOLCS I. \& JASSÓ F., 1961. A szikes talajok genetikus típusai és elterjedésük törvényszerüségei a Duna-Tisza közén. Agrokémia és Talajtan. 10. 173-194.

То́тн, J., 1984. The role of regional gravity flow in the chemical and thermal evolution of ground water. In: Proc. $1^{\text {st }}$ Canadian/American Conference on Hydrogeology, Banff, Alberta, Canada, June 22-26, 1984. 2-39.

То́тн J., 1995. A nagy kiterjedésü üledékes medencék felszín alatti vizeinek hidraulikai folytonossága. Hidrológiai Közlöny. 75. (3) 153-159.

То́тн, T. \& KUTI, L., 1998. Variability of geological conditions and its relations to soil salinization inside a small area. In: Proc. Int. Symp, Sustainable Management of Salt-affected Soils in the Arid Ecosystem,. 21-26 Sept, 1997 (Ed.: Elgala, A.) 123-132. Ains Shams University. Cairo.

То́тн, T. \& KUTI, L., 1999a. Geological factors affecting the salinization of the Nyírölapos sample area (Hortobágy, Hungary). I. General geological characterization, calcite concentration and $\mathrm{pH}$ values of subsurface layers. Agrokémia és Talajtan. 48. $431-444$. 
TóTH, T. \& KUTI, L., 1999b. Geological factors affecting the salinization of the Nyírölapos sample area (Hortobágy, Hungary). II. Multiple relations and the prediction of surface soil salinity. Agrokémia és Talajtan. 48. 445-457.

TÓth, T., Kertész, M. \& PÁszTOR, L., 1998. New approaches in salinity/sodicity mapping in Hungary. Agrokémia és Talajtan. 47. 76-86.

TÓTH T. \& VÁRALLYAY GY., 2001. Egy mintaterület talajának variabilitása a sófelhalmozódás tényezői szerint. Agrokémia és Talajtan. 50. 19-34.

VÁrallyay Gy., 1966a. Duna-Tisza közi talajok sómérlegei. I. Sómérlegek természetes (öntözés nélküli) viszonyok között. Agrokémia és Talajtan. 15. 423-453.

VÁRALLYAY GY., 1966b. A dunavölgyi talajok sófelhalmozódási folyamatai, sóforgalma és sómérlegei. Kandidátusi értekezés. Budapest

VÁRAllyay Gy., 1967. A dunavölgyi talajok sófelhalmozódási folyamatai. Agrokémia és Talajtan. 16. 327-356.

VÁRAllyay Gy., MOLNÁR E. \& RAJKAI K., 1984. Talajtani kutatások. In: Tudományos kutatások a Kiskunsági Nemzeti Parkban (1975-1984) (Szerk.: TóTH K.) 59-96. HUNGEXPO. Budapest.

Érkezett: 2001. március 5. 